\title{
Avoidance Strategies as a Result of Linguistic Overload in Biology Class
}

\author{
Bernhard Müllner, Martin Scheuch \\ University of Vienna, Austrian Educational Competence Centre for Biology \\ (AECC-BIO)
}

\begin{abstract}
Studies in the field of second-language-learners in German showed that students apply different strategies if they are exposed to a linguistic overload in school. These strategies very often result in behaviour of avoidance. In this paper, a case study from biology class illustrates a student named Lela who applies an avoidance strategy: She refuses to read schoolbook texts on her own and the autonomous work on a crossword puzzle, too. To capture the reason for Lela's behaviour this case study uses participatory observation protocols (OP) which are analysed via Key-Incident-Analysis. Moreover, we analysed the respective schoolbook texts and the crossword puzzle. Results reveal that Lela's avoidance strategies are not symptoms of laziness or a lack of interest but linguistic complexity in schoolbook texts and missing support of learning language of schooling.
\end{abstract}

Keywords: avoidance strategy, biology education, language of schooling, Key-Incident-Analysis, case study, linguistic overload

Students should be critical and literate in scientific phrases and ideas in order to successfully participate in society. Language is one key for being scientifically literate and being capable of acting critically with reference to science in the context of their lives. Therefore the conscious use of a particular language is a prerequisite for "comprehension and communication in a subject" (Leisen, 2011, p. 3) as well as the production of new knowledge (Härtig et al., 2015) in school, in this particular case the use of the German language in science class in school. Language should not be restricted to passive/sole transmission of factual knowledge (Kuplas, 2010). Research in biology education (Nitz et al., 2012; Wellington et al., 2001) as well as in language education (Gogolin et al., 2011; Lange, 2012) shows that the demands upon school-based language in science education differs greatly from languages students use in day-to-day situations. One reason for this difference is found in the different contexts of the use of language (Gogolin et al., 2011; Halliday et al., 1993; Lange, 2012; Schleppegrell, 2001). Languages, therefore, differ in linguistic features depending on the day-to-day context or the context of schooling. Enacted language in the context of education in schools is described as "language of schooling" (in German: Bildungssprache: Lange et al., 2010). Introduction into this language of schooling precedes students' understanding of subject as well as un- 
30 derstanding the process of scientific knowledge production and moreover applying this knowledge. Second language learners in German often have specific linguistic problems with language of schooling in German speaking countries (Gogolin et al., 2011). The reasons can be found at structural and functional levels (Nitz et al., 2012) which can be recognized at lexical semantic, syntactic and discursive features (Reich, 2008):

- Lexis and semantics: features of terminology and linked meaning.

- Syntax: features of sentence structure (e.g. compound clause, impersonal constructions).

- Discourse: features of stylistic conventions in discipline specific text types.

Studies show that students with German as second language apply different strategies to meet specific requirements in language of schooling (Komor et al., 2008; Leisen, 2005; Stedje, 2009; Steinmüller, 1987). This contribution is about strategies coined as "communicative strategy of Avoidance" (Steinmüller, 1987) or simple "avoidance strategy" (Leisen, 2005) to deal with such requirements in school biology. ${ }^{1}$ Avoidance strategies have been described as:

- recourse to simple sentence structure;

- recourse to reduced vocabulary;

- falling silent;

- applying standard solutions (Ehlich et al., 2008; Leisen, 2005; Stedje, 2009).

This paper explains observed avoidance strategies from a case study and compares the strategies and findings with previous findings in literature. Yin (2009) describes a case study as "an empirical inquiry that investigates a contemporary phenomenon in depth and within its real-life context" (p. 18). Although case studies are often "recognized among the array of qualitative research choices" (p. 19), they can include qualitative as well as quantitative evidence.

We want to start with an introduction into the case description first to "attract attention to the situation itself" (Funder et al., n. d., p. 18), in the subsequent sections the theoretical literature will be applied to the case.

\section{Detecting behaviours: The case study of Lela}

Lela is 14 years old and attends the last grade of lower secondary school in a Gymnasium (Grade 8) in Vienna. There is a high proportion of students with German as second language in her class. Lela is small compared to her class mates, has dark

1 This phenomenon was described as "communication strategy" by Elaine Tarone since 1978, she created a typology of those communication strategies of second language learners (Tarone, 1981). 
eyes and wears a headscarf. Throughout biology class she sits in the back row.

During one biology lesson the students have to solve a crossword puzzle alone on the basis of two textbook sections within the new topic of metabolism. The questions are about definitions and the students have ten minutes to find the technical terms and finish the puzzle (Table 1). Lela looks in her textbook, skims the two textbook sections, fills in "glucose" in the first row of the crossword puzzle, sets aside her pen and starts a conversation with the observer. She calls his name and asks him for help. He responds that he cannot help her, but she asks him a second time. After refusing to help her a second time she turns to her neighbour and copies the correct terms. She also eavesdrops on her colleagues as they whisper the answers and transfers everything she hears to her crossword. (Observation protocol, OP 28. 5. 2013)

Table 1 Translated questions of Crossword puzzle "metabolism"

Read chapter 1 and 2 and solve the following quiz (sg. means singular)!

1. Technical term for grape sugar.

2. Collective term for indigestible substance from plants.

3. Technical term for multiple sugar.

4. Tooth decay that is supported by too much sugar.

5. Technical term for fructose.

6. Main structural substance in plant cells.

7. Reserve carbohydrate in muscles and liver.

8. Technical term for milk sugar.

9. Multiple sugars, important reserve carbohydrate in plants.

Note: Translation by the authors.

Source: Schermeier et al., 2013, p. 63.

At first it seems that Lela does not like to do the assignment and solve the crossword puzzle on her own as assigned by the teacher. One could impute her being lazy or not interested at all. We want to stay with Lela to further observe her behaviour in order to answer the following questions about the reason for her behaviour:

1. Which regularities and differences can be found in Lela's behaviours in different biology lessons?

2. What factors could have contributed to her behaviours?

\section{Methodology}

To capture the reason for Lela's behaviour the "hidden [...] sense" (Fürstenau, 2004, p. 29) of this incident (Green et al., 1997) has to be worked out until the hidden "metaphorical [...] message" (Gogolin, 1997, p. 34) can be revealed. This case 
32 study uses participatory observation protocols (Datler et al., 2012; Trunkenpolz et al., 2009) to reveal the metaphorical message. The incident described in the introduction originates from a series of participatory observations from 2013. The data collection took place between April and June in a Viennese Gymnasium, which is known for the wide diversity of students of different first languages. The first author observed Lela's interactions with her classmates and her biology-teacher. Eight observation protocols were written containing impressions and results of field observations which were taken once a week for seven weeks including a double period. Collecting data over a longer period enables the researcher to compare the behaviour of Lela in each of the several biology lessons and to work out regularities and differences, which are important to answer research question 1.

\subsection{Key-Incident-Analysis}

To look for the hidden meaning in the observed incident displayed in the introduction we applied Key-Incident-Analysis. This method "enables studying specific aspects of everyday life and reveal[s] cultural practices of a social group without applying a complete ethnography" (Kroon et al., 2000, p. 97). According to Erickson (1986) a key event

[...] is key in that the researcher assumes intuitively that the event chosen has the potential to make explicit a theoretical 'loading'. A key event is key in that it brings to awareness latent, intuitive judgements the analyst has already made about salient patterns in the data. (qu. in Kroon \& Sturm, 2000, p. 99)

The incident (Gogolin et al., 2000) in our context demonstrates a representative situation in biology lessons that have explanatory value for structures of the overall situation (Neumann, 2000, p. 187). During analysis "focus is put on those text passages where a hidden meaning is assumed" (Fürstenau, 2004, p. 29). This focus is especially important for this study in order to identify the factors that led to the behaviour of Lela (research question 2). Therefore, Ericson $(1977 ; 1986)$ characterizes the Key-Incident-Analysis emblematic (Kroon et al., 2000). The word "emblem" originates from Greek and means literally inlay work (Lesky, 1968). The baroque emblem has a tripartite structure (Table 2): (1) the lemma is a short statement that gets to the heart of a moral or a doctrine; (2) the icon is a pictorial representation for the viewer of the doctrine or the moral; (3) the epigram reflects upon the other two parts and has the function to explain them (Schöne, 1993). This tripartite structure is transferred to the structure of the Key-Incident-Analysis (Erickson, 1977; 1986). The title is the lemma, the written Key-Incident complies with the icon and the epigram is represented by analysis and interpretation. Like the icon, the written Key-Incident is a secret to the reader with a hidden meaning which can only be revealed by further analysis and interpretation (Kroon et al., 2000). Therefore, all protocols of the observation are analyzed for further Key-Incidents in search for meaning (Fürstenau, 2004) in order to be able to attribute meaning to Lela's behaviour. 
Table 2 Structure of an emblem (CCO)

\begin{tabular}{|c|c|c|c|}
\hline & Key-Incident & Baroque Emblem & \\
\hline & Title & Lemma & $\begin{array}{l}\text { POTENT ISS I M VS } \\
\text { affectus dinor. }\end{array}$ \\
\hline & Written Key-Incident & Icon & \\
\hline 3. & Analysis and interpretation & Epigram & 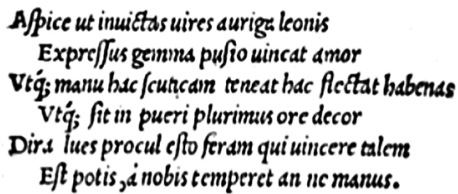 \\
\hline
\end{tabular}

\subsection{Analysis of comprehensibility of the biology textbook}

The first author did not only analyse the eight observation protocols but included the used textbook as well because there could also be hints found that explain Lela's behaviour. The texts in the textbook (Table 4) and the crossword puzzle were analyzed using a statistical linguistic method from Kulgemeyer et al. (2014). The aim of this analysis is to determine the overall "estimation of comprehensibility" (ibid., p. 248) and to get evidence of a possible factor which has contributed to Lela's behaviour while she was skimming the two textbook sections and doing the assignment (research question 2). Therefore, six overall measures of text comprehensibility were calculated: (1) mean length of sentence, (2) indicator of comprehensibility, (3) local and (4) global substantival coherence of texts, (5) proportion of technical terms and (6) proportion of technical terms used only once.

The Measure "Indicator of comprehensibility" (number 2) is a measure that determines whether or not the respective grade can understand this text at all $(\mathrm{K}=$ 11 would mean a text is appropriate for $11^{\text {th }}$ graders). A further measure for comprehensibility of texts is the coherence of texts (number 3 and 4). Coherence is reached if different parts of a text are comprehended by a reader (Kulgemeyer et al., 2014). Starauschek (2006) differentiates between local coherence among consecutive clauses and global coherence of clauses far away of each other. We calculated the local and global substantival coherence. The fifth and sixth measure is the overall use of technical terms in the text and the relation with the last two proportions: Technical terms and technical terms used only once. 
34 Table 3 Measures of text comprehensibility

\begin{tabular}{ll}
\hline Measure & Formula \\
\hline (1) Mean length of sentence & $S=W / S$ \\
(2) Indicator of comprehensibility & $K=0.2656 \times S+0.2744 \times M S / W \times 100-1.694$ \\
(3) Local substantival coherence of text & $I s k=L S K / S \times 100$ \\
(4) Global substantival coherence of text & $g s k=S U B 2 / S U B \times 100$ \\
(5) Proportion of technical terms & $f W=F W / W \times 100$ \\
(6) Proportion of technical terms used only once & $f W 1=F W 1 / W \times 100$ \\
\hline \multicolumn{2}{c}{ Description of variables } \\
\hline$W=$ total count of words & $S=$ total count of sentences \\
$M S=$ count of words with three or more syllables & $L S K=$ count of identical nouns in consecu- \\
& tive clauses \\
$S U B_{2}=$ total count of nouns in text minus nouns & $S U B=$ total count of nouns in text \\
occurring twice or more often & $F W=$ total count of technical terms occur- \\
$F W=$ total count of technical terms & ring only once \\
\hline
\end{tabular}

Note: Formulas and abbreviation of variables were not translated.

Source: Kulgemeyer et al., 2014.

Table 4 Schoolbook texts

Sugar, starch, cellulose, dietary fibres \& Co - Which compounds belong to carbohydrates?

Carbohydrates are composed from the chem- Thus the second syllable refers to the Greek ical elements carbon, hydrogen and oxygen. name for water (= hydros). Carbohydrates are This explains their name. The first syllable produced via photosynthesis in green plants. stems from carbon. The ratio of hydrogen and oxygen is 2:1, like in water.

\begin{tabular}{|c|c|c|c|}
\hline CARBOHYDRATE & SYMBOL & EXAMPLES & OCCURENCE \\
\hline $\begin{array}{l}\text { simple sugar } \\
\text { (monosaccharide) }\end{array}$ & & $\begin{array}{l}\text { grape sugar } \\
\text { (glucose) fruit } \\
\text { sugar (fructose) }\end{array}$ & fruit, honey \\
\hline $\begin{array}{l}\text { disaccharide } \\
\text { (disaccharide) }\end{array}$ & & $\begin{array}{l}\text { cane- or beet sugar } \\
\text { (sucrose) malt } \\
\text { sugar (maltose) } \\
\text { milk sugar (lactose) }\end{array}$ & $\begin{array}{l}\text { reserve substance in fruits } \\
\text { and beets in germinating } \\
\text { grains, beer milk, dairy } \\
\text { products }\end{array}$ \\
\hline \multirow[t]{3}{*}{$\begin{array}{l}\text { multiple sugar } \\
\text { (polysaccharide) }\end{array}$} & & starch & $\begin{array}{l}\text { reserve carbohydrate in } \\
\text { plants - in tubers and } \\
\text { fruits }\end{array}$ \\
\hline & & glycogen & $\begin{array}{l}\text { reserve carbohydrate in } \\
\text { liver and muscular system }\end{array}$ \\
\hline & & cellulose & $\begin{array}{l}\text { structural substance in } \\
\text { plants (mostly cell walls) }\end{array}$ \\
\hline
\end{tabular}


Check the facts for carbohydrates. What benefits do they have? Which problems can they cause in diet?

\begin{tabular}{|c|c|}
\hline PRO & CONTRA \\
\hline $\begin{array}{l}\text { Supply for energy - nerve cells and brain cells } \\
\text { get their energy mostly from grape sugar; } \\
\text { therefore a constant blood sugar level is } \\
\text { important; is controlled by hormones; short- } \\
\text { chain carbohydrates are quickly absorbed by } \\
\text { the blood. }\end{array}$ & $\begin{array}{l}\text { Short-chain sugars are mainly responsible for } \\
\text { emergence of caries; Bacteria break down } \\
\text { sugar in the mouth cavity, the resulting acids } \\
\text { attack the substance of the teeth. }\end{array}$ \\
\hline $\begin{array}{l}\text { Support digestion in form of dietary fibres. } \\
\text { The term originates from the } 19^{\text {th }} \text { century and } \\
\text { includes indigestible compounds from plants - } \\
\text { in these times it was thought that they are } \\
\text { useless, namely ballast. An important dietary } \\
\text { fibre is cellulose. }\end{array}$ & $\begin{array}{l}\text { If one takes more carbohydrates (in particular } \\
\text { simple sugars) as needed for energy supply, } \\
\text { the sugars are stored as fat in the body; } \\
\text { a consequence is increase in weight; } \\
\text { a possible secondary affection is diabetes. }\end{array}$ \\
\hline $\begin{array}{l}\text { The so called "empty carbohydrates" (e.g. } \\
\text { white sugar, in white bread and highly sugared } \\
\text { drinks) give a quick energy supply. }\end{array}$ & $\begin{array}{l}\text { After absorption of the so called "empty } \\
\text { carbohydrates" the blood sugar level rises } \\
\text { quickly, but decreases through hormones } \\
\text { quickly as well. This raises the risk of getting } \\
\text { diabetes. }\end{array}$ \\
\hline
\end{tabular}

Note: Translation by the authors.

Source: Schermeier et al., 2013, p. 62.

\section{Results}

In this section the results are presented: Key-Incidents from the participatory observation and the assessment of the comprehensibility of the related textbook sections. The Key-Incidents are summarized and were named after the taught biological topic. For the used text sections a linguistic statistical analysis is presented and compared with previous results of research.

\subsection{Key-Incident: “Animal experiments”}

Students assembled in groups and got the task to design a role play with the topic "experimental animals" that would be filmed later on. The teacher gave materials and information for preparing that role play. The students had already worked through the material during the lesson before the role play task was assigned. In this lesson the students gathered again to plan the details:

The groups that were formed last lesson each had five minutes to prepare the role play. Lela and her three colleagues (all female) are the first group. At Lela's desk are a soft drink bottle, an orange folder and a paper bag. Right after the starting signal given by the teacher Lela gets up and goes over to her group members who remained seated. With Lela leading the discussion the girls work together to decide who will take which role. She points at each girl who nods approvingly. Two times within the five minutes 
Lela raises her voice above the babble of voices of the whole class: "I enter the scene and say 'There are alternatives!'” When the teacher passes by after four minutes and asks the group whether they need more time for preparation, Lela affirms it immediately. (OP 17. 4. 2013, II. 22-37)

\subsection{Key-Incident: "Nuclear accident"}

After debriefing the film "Die Wolke" (by Gregor Schnitzler, 2006) with the students, the teacher hands out several newspaper articles dealing with nuclear accidents. The following observation was made:

"I want one group working on the topic of Seibersdorf. There has been an accident recently - I hope you read the newspaper every now and then. Ah, and we need groups for Fukushima." The groups assemble. Lela joins with Isabella and Ana. Once they are together they receive three articles about the accident of Seibersdorf. Lela starts reading immediately. [...] The teacher explains: "first read the text, then after you finish reading summarize the text you just read" [...] Lela raises her head from her article. "Third", the teacher continues explaining, "all others are expected to ask questions about the article [...] and then we will conclude the assignment with any remaining open questions [...]". All students start reading their newspaper articles. Lela opens her school bag and takes out a squared paper and a roller pen. The empty paper lies left of her, the newspaper article right in front of her. She starts writing. After a few minutes Isabella looks up and puts her empty sheet of paper in front of her. Lela looks at her neighbour and also to Ana. They decide to write the summary together, Lela puts her pen aside. Isabella writes as Lela dictates the text to her and watches Isabella's writing over her shoulder. After some time Lela starts writing again on her sheet of paper. She looks shortly at the paper of her neighbor. After that the girls discuss how they could structure their summary. They agree on starting the summary with the cause of the accident [...]. (OP 15. 5. 2013, Il. 60-81)

\subsection{Key-Incident: "Metabolism"}

The students are asked to read two texts about the new topic "metabolism" in their textbook and are told to work individually to use the knowledge from the reading to solve the crossword puzzles. After the working phase the teacher makes oral examinations. The following situation could be observed during the working phase:

"Let us open the book to page 62," starts the teacher as she is introducing the next biological topic. The students are asked to solve two crossword puzzles alone that focus on the topic of metabolism. The information about the main nutrients of food (carbohydrates, fat, proteins, etc.) needed to solve the two puzzles can be taken out of two textbook sections. [...] Lela looks for half a minute at the two textbook sections and the book page where the first crossword puzzle is found. The questions ask for technical terms in regards to the field of metabolism. She points with her left index finger at the first question, takes her pen and writes 'glucose' into the first row. She puts the pen aside and looks at Isabella. A few seconds later she looks at her book page and then looks at me: "Could you help me with my task please?" [...] I explain to her, that I attend this class to learn by myself and that I am not able to help her. She asks for help a second time and I try to explain to her why I will not help her. She frowns, knits her eyebrows and turns to Isabella. She looks at Isabella's crossword and transfers 
Isabella's solutions to hers'. Apart from three words the first crossword puzzle is completed. Mia from the front row turns around and whispers the terms cell wall and starch to them. Lela transfers the answers into her crossword, looks at me, and turns her page to the second cross-word puzzle. She leans to her left to Isabella and her colleagues there. "Number one is 'saturated"” states a girl which sits three seats next to Lela. [...] Lela writes 'saturated' into the first row. The teacher starts controlling the crossword puzzles. (OP 28. 5. 2013, Il. 39-57).

\subsection{Statistical measures of the schoolbook texts}

The Key-Incident "metabolism" demonstrates the behaviour of Lela and her work with the textbook. For clarification of the second research question we analyzed the respective schoolbook texts with the several statistical measures. "Comprehensibility as a feature of a text is not directly observable" (Kulgemeyer et al., 2014, p. 242), thus we used the measures presented in the methods section for an estimation of the text comprehensibility.

Table 5 Results of the comprehensibility

\begin{tabular}{ll}
\hline Measure & Formulas \& Results \\
\hline Mean length of sentence & $S=W / S=304 / 31=9.8$ \\
Indicator of comprehensibility & $K=0.2656 \times 304 / 31+0.2744 \times 109 / 304 \times 100$ \\
& $-1.694=10.75$ \\
Local substantival coherence of text & $l s k=L S K / S \times 100=8 / 31 \times 100=25.8 \%$ \\
Global substantival coherence of text & $g s k=S U B 2 / S U B \times 100=61 / 122 \times 100=50 \%$ \\
Proportion of technical terms & $f W=F W / W \times 100=43 / 304 \times 100=14.14 \%$ \\
Proportion of technical terms used only once & $f W 1=F W 1 / W \times 100=15 / 304 \times 100=4.93 \%$ \\
\hline Description of variables \& results & \\
\hline$W=304=$ total count of words & $S=31=$ total count of sentences \\
$M S=109=$ count of words with three or more & $L S K=8=$ count of identical nouns in consecu- \\
syllables & tive clauses \\
$S U B_{2}=61=$ total count of nouns in text minus & $S U B=122=$ total count of nouns in text \\
nouns occurring twice or more often & \\
$F W=43=$ total count of technical terms & $F W 1=15=$ total count of technical terms \\
& occurring only once
\end{tabular}

Note: The resulting numbers are compared with literature and interpreted in conjunction with the observations in the discussion in facet 2.

Additional information for the calculations is summed up in the following section: There were difficulties in calculating of the mean length of a sentence because a table included in the text that contained information where semicolons were used as punctuations. We applied the rule that each row in the table counts for a sentence, each semicolon counts as a full stop. For calculating the local substantival coher- 
38 ence of text the pairs of nouns in consecutive clauses were counted (= LSK): (2) / (3); (4) / (5); (5) / (6); (6) / (7); (9) / (10); (13) / (14); (24) / (25); (25) / (26). The count of paired sentences is 8 . Finally, the total count of technical terms in total and technical terms used only once was determined. In order to proceed with the research and analysis rules to define technical term in this particular study must be set up. These two texts were the first in the schoolbook on the topic of metabolism. Therefore, all terms have to be looked at as technical terms which are necessary for communication with experts in this field. This also applies to words which are used in day-to-day contexts. For example: One can assume that a 14 year old has already heard of carbohydrates in school as well as in everyday life. But, it cannot be taken for granted that the students have the understanding to attribute the right meaning to the term "carbohydrates" (Berck, 1999), and, as a consequence, we qualify this term as a technical term. Taking these rules into account, the following technical terms were identified: starch, cellulose, dietary fibers, carbohydrates, carbon, hydrogen, photosynthesis, monosaccharide, simple sugar, disaccharide (and the German translation), glucose, fructose, sucrose, reserve substances, maltose, lactose, polysaccharide, glycogen, cell wall, hormone, diabetes, constant. The total amount of technical terms is 43 , and the total amount of technical terms used only once is 15 .

\section{Discussion and theoretical outlook}

The first observation of Lela's behaviour at the beginning of this article has shown a student that does not follow the instructions of the teacher but copies the solutions of the crossword assignment from her peers (OP 28. 5. 2013, Il. 50-55). She only skims the text instead of reading accurately (OP 28. 5. 2013, l. 39). We want to understand her behaviour in this biology class. Therefore, her behaviour in other biology lessons in the light of the research questions was taken into account. In this section different facets of the biology class are discussed to paint the picture of Lela's behaviour and to develop possibilities of transforming the biology class into a multilingual environment that is sensitive to the language needs of the various students.

\subsection{Facet 1: Lela's behaviour as a reaction to forms of teaching and social arrangement}

If the Key-Incident metabolism is compared to the other two Key-Incidents nuclear accidents and animal experiments it is obvious that Lela's behaviour was totally different. During the incidents nuclear accidents and animal experiments she engages actively in biology class which was demonstrated in her having a leading position during the preparation for the role play (OP 17. 4. 2013, l. 32), and during the task of the summaries about nuclear accidents, when she dictates a text to her group and 
also writes the summary by herself (OP 15. 5. 2013, Il. 77-78). It is remarkable that in both lessons the social arrangement is group work, where the observed students learn by discussing (biological relevant) phenomena. Student discussion enables those learners - and especially Lela - to engage actively in speaking language, like Schmölzer-Eibinger et al. (2012) reports, ultimately allowing the students to determine and understand meanings in a social context (Heintze, 2009). Another difference between the incidents analyzed is that the students in the incident metabolism work on the crossword assignment alone to prepare for being tested in a teacher centered test format afterwards. According to Lengyel (2012) a teacher centered test format is characterized by the teacher asking a student a question that only has one correct answer. In the other incidents the students prepare for a role play and a short presentation of the summaries of the newspaper articles. In the course of the latter incidents the students with second language German have the possibility to solve collaboratively their tasks without time pressure. Additionally, both learning environments draw on supportive characteristics in terms of language which are proposed by Gibbons (2002) and Kniffka (2010) for a language sensitive specialized class:

- During the animal experiments incident the students are confronted with an authentic situation for communication via the role play (Kniffka, 2010). During the planning phase of the group activity the learners get the chance to plan and try out complex linguistic utterances (Kniffka, 2010) and are able to find answers to problems (Schmölzer-Eibinger et al., 2012) as a result of the authenticity of this particular assignment. This setting has two advantages: the main proportion of enacted language is done by the students instead of the teacher (Heintze, 2009) and the students do not have to answer to the teacher within seconds (Kniffka, 2010).

- Enough time for planning linguistic utterances was also available in the "nuclear accidents" assignment. However, in this case, the planning is written down in summaries. For Schmölzer-Eibinger et al. (2012) writing can be seen as deceleration of lessons because by "expanded situations with language" the students get the possibility to produce more complex statements. Compared to the "animal experiments" incident there was a cooperative written task included. This cooperative writing enables the students to work on certain wordings, to negotiate meaning with each other (Heintze, 2009), and to refine and reflect their writing continuously (Schmölzer-Eibinger et al., 2012).

In both Key-Incidents the learning of Biology is linked to language learning because the learning environment and the tasks link the use of competences within the language of schooling and learning the biological topics. Therefore, acquisition of new knowledge and expansion of language competences is made possible (Lange et al., 2010).

From her active engagement we conclude that Lela feels comfortable in certain learning environments. She communicates with her colleagues, helps writing texts, conscientiously produces her own texts and explicitly plans her own text script 
40 for the role play: "I enter the scene and say 'There are alternatives!" (OP 17. 4. 2013 , l. 35). What is the cause for Lela to show different behaviour in the Metabolism-Key-Incident? One reason can be found in the social form of the task and, hence, the pre-scribed interactions. Unlike the other Key-Incidents Lela has to work on her own and is not able to exchange the results with her colleagues during the task. An aggravating factor is the limited time for filling in the crossword and the testing by the teacher afterwards. Lela applies an avoidance strategy as a reaction to the (non-) social form of this task and the stress: she refuses to read the schoolbook texts on her own and refuses to work autonomously on the crossword. Maybe the difficulty of the respective schoolbook text further encouraged her refusal and lead her to seek help.

In psychology avoidance strategies can be seen as the "core component of all fears" (Meszaros, 2009, p. 763). In Lela's case the fear of being tested and not knowing the correct answer could be her motive for her "maintenance of image" (Stedje, 2009) to show "as few language deficiencies as possible to the communication partner" (Stedje, 2009, p. 160). Lela is in an emergency and seeks help from the observer: "Could you help me with my task please?" (OP 28. 5. 2013, Il. 45-46). Tarone (1981) describes this form of communication strategy as "appeal of assistance". Stedje (2009) calls it the "help seeking strategy". A characteristic of this strategy form is meta-communicative utterances from students like actively verbally seeking help (Stedje, 2009), like in Lela's case.

The strategy appeal of assistance does not bring the expected result for Lela. She turns to her classmates but does not ask for help but copies their solutions into her crossword (OP 28. 5. 2013, l. 51). All of the students around Lela turn this task that was meant to be done individually as assigned by the teacher into group work (OP 28. 5. 2013, Il. 52-53). However, in this improvised group work, all of the students, including Lela, do not engage in collaboration to determine the meanings of the terms and texts (Schmölzer-Eibinger et al., 2012) but, communicate with each other to simply exchange correct technical terms with the obvious aim to shine in front of the teacher in the testing afterwards. The main question needing to be determined by the instructor for this particular task is whether the task fulfills its function, in particular: are the technical terms correctly identified and transferred to the crossword? Gropengießer's definition of terms (2010) and also Reich's (2008) features of language of schooling help us to answer this question. Lexical and semantical features of language of schooling come along with an attribution of meaning. This applies to technical terms as well. A term is never part of reality itself (Gropengießer et al., 2010); the used verbalisms for the term are only representatives and one cannot know whether the term is understood or only used as an empty phrase (Berck, 1999). Based on the observation, one can assume that Lela could not attribute meaning to the technical terms. Except for one technical term, which was found after a short glimpse into the schoolbook and transferred into the first row, all other crossword terms were copied from her colleagues. Therefore, the aim of the task was not reached. 
The inference that can be made from these examples is that Lela reacted to two different learning environments in different ways. Lela was intensively engaged when she was a part of a student centered group work but, she was not actively engaged in learning during the assignment for individuals with schoolbook texts in metabolism. Key factors seem to be the missing interaction with her classmates, the time pressure, and the final testing. One clue for her need for interaction was the request for help. It was remarkable that Lela did not ask for the solution of the crossword (e.g. "Oh - I know it but ah how is it called", Stedje, 2009, p. 160) but rather asked for help at the level of the task itself.

\subsection{Facet 2: Lela's behaviour as a reaction to the schoolbook texts}

In the previous facet, the social aspects of the learning environment were discussed as drivers for Lela's avoidance strategy. In this facet, we analyze the schoolbook and the possible reasons why Lela turned away from the book shortly after having a glimpse into her textbook (OP 15. 5. 2013, l. 39) instead of working on her own like in the incident nuclear accidents and exchanging afterwards (OP 15. 5. 2013, II. 74-81). Statistical analysis on the basis of the language can be inferred that the features of the schoolbook texts are one reason for Lela's behaviour. For further reasoning we compare the results of the measures with reference values from other schoolbook studies (Rabe et al., 2005; Starauschek, 2006):

Table 6 Results of the comprehensibility compared to recommended reference values

\begin{tabular}{|c|c|c|c|}
\hline & Schoolbook texts & Reference value & Source \\
\hline Indicator of comprehensibility & $K=10.75$ & - & - \\
\hline $\begin{array}{l}\text { Local substantival coherence } \\
\text { of text }\end{array}$ & $l s k=25.8 \%$ & $\begin{array}{l}l s k=51 \% \\
41 \%<l s k<65 \%\end{array}$ & Starauschek (2006) \\
\hline $\begin{array}{l}\text { Global substantival coherence } \\
\text { of text }\end{array}$ & $g s k=50 \%$ & $\begin{array}{l}g s k=80 \% \\
70 \%<g s k<89 \%\end{array}$ & Starauschek (2006) \\
\hline Proportion of technical terms & $f w=14.14 \%$ & $f w<7 \%$ & Rabe et al. (2005) \\
\hline $\begin{array}{l}\text { Proportion of technical terms } \\
\text { used only once }\end{array}$ & $f w_{1}=4.93 \%$ & $f w_{1}<3 \%$ & Rabe et al. (2005) \\
\hline
\end{tabular}

The comparison of the schoolbook texts (given in the supplementary material in German and translated into English) with the set of reference values shows that all of our detected measures are worse that they should be, regardless of being higher or lower.

- The indicator for comprehensibility of $10.75(K)$ is relatively high for $8^{\text {th }}$ graders that means roughly two levels too high. Although the measure $K$ cannot foresee which text fits to which level and can be a coarse measure as to whether the text is appropriate or not (Kulgemeyer et al., 2014). 
42 - Both, the local and global substantive coherence are low. That means there is a small amount of nouns that are repeated in the subsequent clause (local) or in the text in general (global). A gain of knowledge by the students is therefore made difficult.

- Finally, the proportion of the technical terms shows another difficulty of the schoolbook text. Approximately $14 \%$ technical terms is a very high proportion, 43 technical terms in a relatively short text is not easy to deal with. Moreover $4 \%$ of these technical terms are only used once!

A high proportion of technical terms are a recurring theme in science education research. A lot of papers state "that science education is overloaded with technical terms" (Nitz et al., 2012, p. 124 - they also give a thorough literature review on that topic) and that a reduction of using the technical terms is needed (ibid.). Schoolbooks are especially overloaded with technical terms. A study of Merzyn (1994) found that:

- Every sixth word is a technical term and every $25^{\text {th }}$ word is a new technical term.

- In schoolbooks, $50 \%$ of the technical terms are only occurring once.

A similar result could be found in the schoolbook used by Lela. Besides the high amount of technical terms the typical syntax for the language of schooling is obvious (Reich, 2008). The combination of the measures mean length of sentences, the indicator of comprehensibility and cohesion of the text with the syntax results in very low comprehensibility for the students. Additionally the texts have linguistic difficulties for second language learners: passive constructions ("carbohydrates are formed"; "carbohydrates are composed of...”), chains of attributes ("indigestible plant based compounds"), and participial attributes ("germinating"). If second language learner students recognize that they do not understand sentence construction, they react with avoidance strategies (Kemp et al., 2008).

Our assumption that the schoolbook texts lead to frustration from Lela is strengthened after the text analysis. The reasons can be found in lexical semantical and syntactical features: Due to the high amount of technical terms and complex sentence structures Lela has "problems of linguistic comprehensibility" (Kuplas, 2010 , p. 187) that have led to her avoidance of reading the schoolbook text and completing the crossword on her own. Fear of the testing and linguistic deficiencies force her to ask for help. She did not get the help; therefore she copied the solution to finish the task.

\subsection{Conclusion: Supportive elements of learning environments in order to counter avoidance strategies and theoretical underpinnings}

Both facets of the observed biology class revealed that Lela showed different behaviours in different learning environments. There were several characteristic features for supportive language learning environments that helped Lela in participating in the class and assignments: 
- Enough planning time for linguistic utterances

- Working in small groups

- Active communicative engagement

- Authentic situations for embedding communication

- Writing as a deceleration of lessons

Each of these features is a supportive element of learning environments for students learning German as second language (Gibbons, 2002; Kniffka, 2010) on their way to master language of schooling as well (Lange et al., 2010). These supportive elements scaffold the learning "in the zone of proximal development" (Lange et al., p. 32). Gibbons (2002) and Kniffka (2010) also use this metaphor of scaffolding that originates from the social constructivist learning theory by Vygotsky (1987). With the help of instructional planning and interaction in the lessons the "gap between the ability of a learner and the goals that are reachable with full support" (Kniffka, 2010, p. 1) should be filled. Although we do not have a text analysis of the Key-Incidents animal testing and nuclear accidents, we can infer from Lela's behaviour that the supportive features for linguistic development gave her the possibility to deal with potential difficulties.

In Key-Incident metabolism she is confronted with a learning environment that is not very supportive in terms of the given principles for instruction planning and interaction (Gibbons, 2002; Kniffka, 2010). Specifically the schoolbook texts are far from the competence level from the class (Kniffka, 2010) and lead to avoidance behaviour by Lela. The analysis of comprehensibility of the biology textbook, especially on the level of technical terms, showed that the difficulties for learning the language of schooling may be contributed to her troubles accomplishing the task. Linguistic overload found at lexical semantical and syntactical levels were not softened by supportive linguistic scaffolding features. Lela's missing previous knowledge of the German language contributed as well. In addition to interaction with bad local and global text cohesion, Lela's comprehension of the texts is insufficient for fulfilling the teacher's task.

Due to the complexity of the schoolbook text and missing linguistic scaffolding Lela's avoidance behaviour demonstrated a new aspect that has not been described in literature yet. Leisen (2005), Ehlich et al. (2008) and Stedje (2009) described avoidance behaviour in the context of "language production (reading \& writing)" (Leisen, 2005, p. 2). Lela shows avoidance strategy based on perception of language. Her strategy of not reading the schoolbook text equates falling silent in terms of language production. In both cases the "transmission of information stops totally" (Stedje, 2009, p. 160). Interesting in her case is the development of further strategies to reach the goal, to fill in the crossword puzzle. As a result of her avoidance of reading the text further hindered the autonomous completion of the task ultimately resulting in Lela asking for help and copying the answers. Thus, she shows not only linguistic but also a methodological avoidance behaviour. 


\section{References}

Berck, K. H. (1999). Biologiedidaktik. Grundlagen und Methoden. Wiebelsheim: Quelle und Meyer.

Datler, W., \& Trunkenpolz, K. (2012). Zwischen Teilhabe und Teilnahme. Methodologisches und Kasuistisches zum Wechselspiel von Abgrenzung und Verstrickung in einem geragogischen Forschungsprojekt. In E. Kleinau \& B. Rendtorff (Eds.), Eigen und anders - Beiträge aus der Geschlechterforschung und der psychoanalytischen Pädagogik (pp. 163-181). Opladen: Verlag Barbara Rudrich.

Ehlich, K., Bredel, U., \& Reich, H. H. (2008). Sprachaneignung - Prozesse und Modelle. In Bundesministerium für Bildung und Forschung (Ed.), Referenzrahmen zur altersspezifischen Sprachaneignung (pp. 63-82). Bonn, Berlin: BMBF.

Erickson, F. (1977). Some approaches to inquiry in school-community ethnography. Anthropology and Education Quarterly, 8(3), 58-69.

Erickson, F. (1986). Qualitative methods in research on teaching. In M. C. Wittrock (Ed.), Handbook of research on teaching (pp. 119-161). New York: Macmillan.

Funder, A., Jedletzberger, A., Kaltseis, R., \& Weizsaecker, E. (n. d.). Infant Observation als Forschungsmethode. Ein Forschungsbericht. Retrieved from https: //fedora. phaidra.univie .ac.at/fedora/get/o:37850/bdef:Content/get

Fürstenau, S. (2004). Mehrsprachigkeit als Kapital im transnationalen Raum. Perspektiven portugiesischsprachiger Jugendlicher beim Übergang von der Schule in die Arbeitswelt. Münster: Waxmann.

Gibbons, P. (2002). Scaffolding language. Scaffolding learning. Teaching second language learners in the mainstream classroom. Portsmouth: Heinemann.

Gogolin, I. (1997). Einführung in die Fallstudie "Großstadt-Schule". Zu theoretischem Rahmen, Fragestellungen und Methoden des Forschungsprojekts. In I. Gogolin \& U. Neumann (Eds.), Großstadt Grundschule: eine Fallstudie über sprachliche und kulturelle Pluralität als Bedingung der Grundschularbeit (pp. 3-46). Münster: Waxmann.

Gogolin, I., \& Kroon, S. (2000). Einsprachige Schule, mehrsprachige Kinder: Erfahrungen aus einem international vergleichenden Projekt über Unterricht in der Sprache der Majorität. In I. Gogolin \& S. Kroon (Eds.), "Man schreibt, wie man spricht”. Ergebnisse einer international-vergleichenden Fallstudie über Unterricht in vielsprachigen Klassen (pp. 1-26). Münster: Waxman.

Gogolin, I., \& Lange, I. (2011). Bildungssprache und Durchgängige Sprachbildung. In S. Fürstenau \& M. Gomolla (Eds.), Migration und schulischer Wandel: Mehrsprachigkeit (pp. 107127). Wiesbaden: VS Verlag für Sozialwissenschaften.

Green, J., \& Bloome, D. (1997). Ethnography and ethnographers of and in education. A situated perspective. In J. Flood, D. Lapp, \& S. B. Heath (Eds.), Handbook of research on teaching literacy through the communicative and visual arts (pp. 181-202). New York: Macmillan.

Gropengießer, H., Kattmann, U., \& Krüger, D. (2010). Biologiedidaktik in Übersichten. Hallbergmoos: Aulis-Verlag.

Halliday, M. A. K., \& Martin, J. R. (Eds.). (1993). Writing science: Literacy and discursive power. Pittsburgh: University of Pittsburgh Press.

Härtig, H., Bernholt, S., Prechtl, H., \& Retelsdorf, J. (2015). Unterrichtssprache im Fachunterricht - Stand der Forschung und Forschungsperspektiven am Beispiel des Textverständnisses. Zeitschrift für Didaktik der Naturwissenschaften, 21(1), 55-67.

Heintze, A. (2009). Wege zur durchgängigen Sprachbildung: Ein Orientierungsrahmen für Schulen. Berlin: FörMig. Retrieved from http://www.foermig-berlin.de/materialien/Wege_zur _durchgaengigen_Sprachbildung.pdf.

Kemp, R. F., \& Bredel, U. (2008). Morphologisch-syntaktische Basisqualifikation. In Bundesministerium für Bildung und Forschung (Ed.), Referenzrahmen zur altersspezifischen Sprachaneignung, Forschungsgrundlagen (pp. 77-102). Berlin: BMBF.

Kniffka, G. (2010). Scaffolding. pro DaZ. Deutsch als Zweitsprache in allen Fächern. Retrieved from https://www.uni-due.de/im-peria/md/content/prodaz/scaffolding.pdf. 
Komor, A., \& Reich, H. H. (2008). Semantische Basisqualifikation. In Bundesministerium für Bildung und Forschung (Ed.), Referenzrahmen zur altersspezifischen Sprachaneignung (pp. 49-62). Bonn, Berlin: BMBF.

Kroon, S., \& Sturm, J. (2000). "Key Incident Analyse" und "internationale Triangulierung" als Verfahren in der empirischen Unterrichtsforschung. In C. Kammler \& W. Knapp (Eds.), Empirische Unterrichtsforschung und Deutschdidaktik (pp. 96-114). (Diskussionsforum Deutsch; No. 5). Hohengehren: Schneider Verlag.

Kulgemeyer, C., \& Starauschek, E. (2014). Analyse der Verständlichkeit naturwissenschaftlicher Fachtexte. In D. Krüger, I. Parchmann, \& H. Schecker (Eds.), Methoden in der naturwissenschaftsdidaktischen Forschung (pp. 241-253). Berlin: Springer-Verlag.

Kuplas, S. (2010). Deutsch als Zweitsprachenförderung im Biologieunterricht. In B. Ahrenholz (Ed.), Fachunterricht und Deutsch als Zweitsprache (pp. 185-202). Tübingen: Narr Verlag.

Lange, I. (2012). Von ,Schülerisch' zu Bildungssprache: Übergänge zwischen Mündlichkeit und Schriftlichkeit im Konzept der Durchgängigen Sprachbildung. In S. Fürstenau (Ed.), Interkulturelle Pädagogik und Sprachliche Bildung (pp. 123-142). Wiesbaden: Springer.

Lange, I., \& Gogolin, I. (2010). Durchgängige Sprachbildung: Eine Handreichung. Münster: Waxman.

Leisen, J. (2005). Sprachhilfen für Schüler mit Migrationshintergrund. Unterricht Physik, 3, 21-25.

Leisen, J. (2011). Handbuch Sprachförderung im Fach: Sprachsensibler Fachunterricht in der Praxis. Bonn: Varus Verlag.

Lengyel, D. (2012). Unterrichtsinteraktion in sprachlich heterogenen Klassen. In S. Fürstenau (Ed.), Interkulturelle Pädagogik und Sprachliche Bildung (pp. 143-161). Wiesbaden: Springer.

Lesky, G. (1968). Barocke Embleme in Vorau und anderen Stiften Österreichs. Ein Vademecum für den Kunstwanderer. Graz: Styria.

Meszaros, K. (2009). Vermeidungsverhalten. In G. Stumm \& A. Pritz (Eds.), Wörterbuch der Psychologie (p. 763). Wien: Springer-Verlag.

Merzyn, G. (1994). Physikschulbücher, Physiklehrer und Physikunterricht. Kiel: IPN.

Neumann, U. (2000). "Man schreibt, wie man spricht, wie man schreibt”: Über Sprachunterricht in einer deutschen Grundschulklasse. In I. Gogolin \& S. Kroon (Eds.), "Man schreibt, wie man spricht". Ergebnisse einer international-vergleichenden Fallstudie über Unterricht in vielsprachigen Klassen (pp. 187-209). Münster: Waxman.

Nitz, S., Nerdel, C., \& Prechtl, H. (2012). Entwicklung eines Erhebungsinstruments zur Erfassung der Verwendung von Fachsprache im Biologieunterricht. Zeitschrift für Didaktik der Naturwissenschaften, 18, 117-139.

Rabe, T., Starauschek, E., \& Mikelskis, H. F. (2005). Textkohärenz und Selbsterklärung beim Lernen mit Texten im Physikunterricht: Ergebnisse einer Vorstudie zur lokalen Textkohärenz. In V. Nordmeier (Ed.), CD-ROM zur DPG-Tagung 2004 in Düsseldorf.

Reich, H. (2008). Materialien zum Workshop "Bildungssprache: Unveröffentlichtes Schulungsmaterial für die FÖRMIG-Weiterqualifizierung Berater (in) für sprachliche Bildung, Deutsch als Zweitsprache. Hamburg: Universität Hamburg.

Schermeier, A., Weisl, H., \& Dagmar, M. (2013). bio@school 4. Wien: Veritas-Verlag.

Schleppegrell, M. J. (2001). Linguistic features of the language of schooling. Linguistics and Education, 12(4), 431-459.

Schmölzer-Eibinger, S., Dorner, M., Langer, E., \& Helten-Pacher M.-R. (2012). Handbuch: Sprachförderung im Fachunterricht in sprachlich heterogenen Klassen. Graz: Fachdidaktik Zentrum der GeWi-Fakultät Graz.

Schöne, A. (1993). Emblematik und Drama. Im Zeitalter des Barock. München: C. H. Beck-Verlag.

Schnitzler, G. (2006). Die Wolke [Film]. Germany: Clasart Film + TV Produktion.

Starauschek, E. (2006). Der Einfluss von Textkohäsion und gegenständlichen externen piktoralen Repräsentationen auf die Verständlichkeit von Texten zum Physiklernen. Zeitschrift für Didaktik der Naturwissenschaften, 12, 159-175. 
46 Stedje, A. (2009). Sprechabsicht und Lückenindikatoren: Zur Problematik der Kommunikationsstrategien. Zeitschrift für Germanistische Linguistik, 10(2), 156-172.

Steinmüller, U. (1987). Sprachentwicklung und Sprachunterricht türkischer Schüler (Türkisch und Deutsch) im Modellversuch “Integration ausländischer Schüler in Gesamtschulen”. In Pädagogisches Zentrum (Ed.), Gesamtschulinformationen, 1, 207-315.

Tarone, E. (1981). Some thoughts on the notion of communication strategy. TESOL Quarterly, 15(3), 285-295.

Trunkenpolz, K., Datler, W., Funder, A. \& Hover-Reisner, N. (2009). Von der Infant Observation zur Altersforschung. Die psychoanalytische Methode des Beobachtens nach dem Tavistock-Konzept im Kontext von Forschung. Zeitschrift für Individualpsychologie, 34 (3), $330-351$.

Vygotsky, L. S. (1987). Thinking and speech. In R. Reiber \& A. Carton (Eds.), The collected works of L. S. Vygotsky, Vol. 1: Problems of general psychology (pp. 39-285). New York: Plenum Press.

Wellington, J. \& Osborne, J. (2001). Language and literacy in science education. Buckingham: Open University Press.

Yin, R. K. (2009). Case Study Research. Design and Methods. Thousand Oaks: Sage Inc.

Mag. Bernhard Müllner

Austrian Educational Competence Centre Biology (AECC-BIO)

University of Vienna

Porzellangasse 4/2/2, A-1090 Vienna

bernhard.muellner@univie.ac.at

Mag. Dr. Martin Scheuch

Austrian Educational Competence Centre Biology (AECC-BIO)

University of Vienna

and

University College for Agricultural and Environmental Education Angermayerg. 1, A-1130 Vienna martin.scheuch@agrarumweltpaedagogik.ac.at 